\title{
THE MACCABEAN LITERATURE AND HEBREWS: SOME INTERTEXTUAL OBSERVATIONS
}

Gert J. Steyn
Department of New Testament Studies, Faculty of Theology
University of Pretoria
Private Bag X20
Hatfield, 0028
South Africa
E-mail: Gert.Steyn@up.ac.za
(Received 08/03/2014: Accepted 01/04/2015)

\begin{abstract}
Several common motifs and linguistic similarities between the books of the Maccabees and the book of Hebrews were noted in the past by scholars in random remarks and ad hoc statements. These relations and similarities deserve further investigation. It is therefore the intention of this paper to compare the Maccabean literature and Hebrews with each other in order to present a brief synopsis of a few selected motifs. Some prominent common motifs that will receive attention include the Abrahamic promise and the Aqedah, priests with royal functions, faith heroes and endurance, instruction of the Scriptures, and the Canticum Mosis. It is hoped that this comparison of common motifs will result in first a closer understanding of whether the unknown author of Hebrews was familiar with the books of the Maccabees, and secondly a better understanding of the provenance of Hebrews in particular.
\end{abstract}

\section{INTRODUCTION}

The term "intertextuality" was coined by poststructuralist literary critics, such as Kristeva and Barthes, "to describe every literary text whose existence and meaning is predicated in relationship to other texts, whether spoken or written, earlier or later" (Wall 2000:541). The meaning of a text is thus shaped by its relationships with other texts (Stead 2012:355). Any text enters "into a dialogue with the texts extant at the time it was written" and "continues to contribute in a dialogue with other texts" (Stead 2012:360). In the field of biblical studies, intertextuality became "an umbrella term that encompasses both innerbiblical interpretation and synchronic intertextuality" (Stead 2012:356). Intertextuality in biblical scholarship, therefore, "studies the many 
interrelationships between particular biblical texts. It treats the role of tradition in the development of biblical literature, especially as later traditions build upon and reinterpret earlier traditions" (Hauser 2012-2014).

Hence, every text is an inter-text, a patchwork of ideas, concepts and motifs compiled from other texts - written or oral - in order to form a new text. This textual tapestry, or intertexture, provides a picture, or a snapshot, of an author's compilation of his pretexts and the author's hermeneutic at play in engaging with these pretexts. Such concepts, ideas and motifs found in inter-texts - and their commonalities with particular pre-texts - might provide clues, or traces, of the reception of certain trajectories by a certain author. Several such common motifs between the books of the Maccabees and the book of Hebrews were noted in the past by scholars in random remarks and ad hoc statements. ${ }^{1}$ These relations and similarities deserve further investigation. It is thus the intention of this study to compare the Maccabaean literature and Hebrews in order to present a brief synopsis of only some selected motifs. Some prominent common motifs that will receive attention include the Abrahamic promise and the Aqedah, priests with royal functions, faith heroes and endurance, instruction of the Scriptures, and the Canticum Mosis. This study therefore intends to make some inter-textual observations by identifying and commenting on analogous motifs in the books of the Maccabees and the book of Hebrews. Two questions in particular arise in the light of this relationship between Maccabees and Hebrews. First, was the unknown author of Hebrews familiar with the books of the Maccabees? Second, might some of these inter-textual similarities between common motifs - particularly in 1 Maccabees, in Philo's works, and in Hebrews - possibly point to an Egyptian context? With this brief survey of common motifs, we hope to get somewhat closer to answering these questions.

1 So, for instance, in commentaries on Hebrews by Attridge (1989), Bruce (1985), Ellingworth (2000), Grässer (1990; 1993; 1997), Karrer (2002; 2008), Koester (2001), Lane (1991; 1998), O’Brien (2010), and Weiss (1991). Ellingworth (2000:37), the commentator who probably presents the most intertextual references between Hebrews and the Maccabaen literature, states for instance, "All explicit quotations are drawn from the Hebrew canon, but there are frequent points of contact with the language of deuterocanonical writings (especially 1-4 Maccabees and Wisdom), and allusions to intertestamental events." 


\section{THE ABRAHAMIC PROMISE ${ }^{2}$ AND THE AQEDAH ${ }^{3}$}

The unknown author of Hebrews explicitly quotes LXX Gen 21:12 (ő $\tau$ غ่ $v$ I $\sigma \alpha \alpha \kappa$

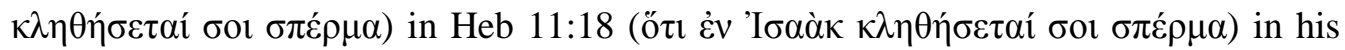
narrative on Abraham (11:11-12, 17-19). Genesis 21 was read during the occasion of the Jewish New Year (Kistemaker 1961:50). Being God's covenant with Abraham, one can expect that references to this particular verse (Gen 21:12) are often found in Jewish literature. It appears as a reference outside the Pentateuch, for instance, in 1 Chr 16:16 with a repetition of that phrase again in Ps 105:9. Interesting, though, is that there are no traces of any explicit citation of this phrase, neither in the Old Testament literature, nor amongst the Dead Sea Scrolls.

The quotation from Gen 21:12 was already known in early Christianity as Paul quoted it in his Letter to the Romans (9:7). Hebrews highlights two aspects regarding the Abraham tradition: First, God's promise that he would receive "descendants as numerous as the stars in the sky and as countless as the sand on the seashore" (11:12), and secondly, God's test of Abraham to offer Isaac as a sacrifice (11:17).

\section{The Abrahamic promise}

The motif of the Abrahamic Promise is strikingly present in the Hellenistic-Jewish literature between the second century B.C.E. and the second century C.E. It surfaces, for instance, in several references and allusions such as in 2 Macc 1:1-2 (second century B.C.E.) and in 4 Ezra 3:15-16 (first century C.E.). ${ }^{4}$

\begin{tabular}{|c|c|c|}
\hline 2 Macc 1:2 & 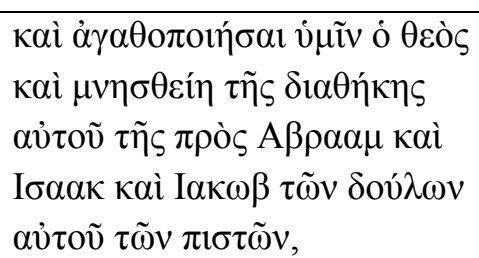 & $\begin{array}{l}\text { May God do good to you, and } \\
\text { may he remember his covenant } \\
\text { with Abraam and Isaak and } \\
\text { Jakob, his faithful slaves (NETS) }\end{array}$ \\
\hline
\end{tabular}

2 See Sutherland (1983:337-343).

3 Cf. Steyn (2011:213): “Abraham's obedience to God's test, his willingness to sacrifice his only son, and particularly Isaac's submission to the will of his father, made the Aqedah a popular story in Jewish circles."

4 Cf. Gen 15:8-21 (Stone 1990:71). 


\begin{tabular}{|l|l|l|}
\hline 4 Ezra 3:15- & $\begin{array}{l}\text { Et disposuisti ei testamentum } \\
\text { aeternum et dixisti ei, ut non } \\
\text { umquam derelinquas semen } \\
\text { eius. Et dedisti ei Isaac, et } \\
\text { Isaac dedisti Iacob et Esau. }\end{array}$ & $\begin{array}{l}\text { You made with him an } \\
\text { everlasting covenant, and } \\
\text { promised him that you would } \\
\text { never forsake his descendants; } \\
\text { and you gave him Isaac, and to } \\
\text { Isaac you gave Jacob and Esau. }\end{array}$ \\
\hline
\end{tabular}

The Abrahamic Promise was also well known and oft quoted by Philo of Alexandria (20 B.C.E-50 C.E.). ${ }^{6}$ Also a part of the verse under discussion here, namely Gen

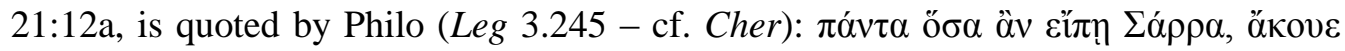

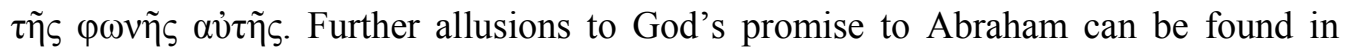
Philo's Her. 313 (where he quotes Gen 15:18) as well as in Philo's Somn. 1.3.

\begin{tabular}{|c|c|}
\hline \multirow[t]{2}{*}{ Philo, Her. 313} & 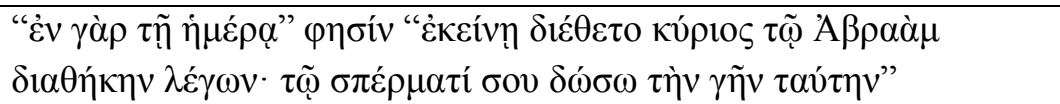 \\
\hline & $\begin{array}{l}\text { "Because on that day", he says, "the Lord made a covenant with } \\
\text { Abraham, stating: To your seed will I give this land." }\end{array}$ \\
\hline \multirow[t]{2}{*}{ Philo, Somn. 1.3} & 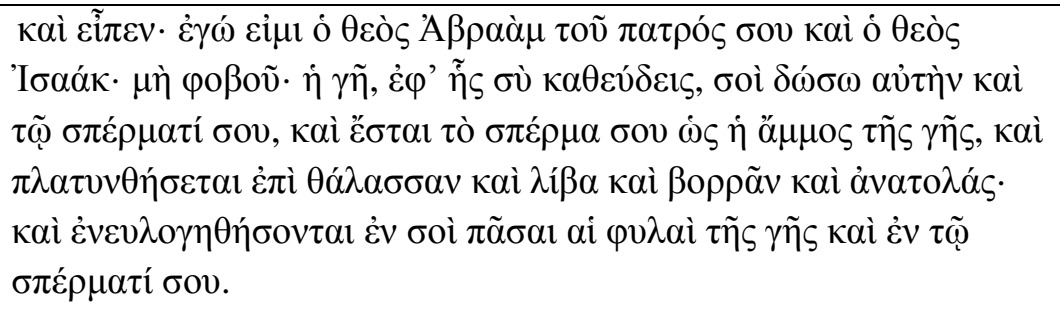 \\
\hline & $\begin{array}{l}\text { and he said: "I am the God of your father Abraham and the God of } \\
\text { Isaac. Do not be afraid! The land on which you sleep - I will give it } \\
\text { to you and to your seed, and your seed shall be like the dust of the } \\
\text { earth, and it shall be multiplied as the sand on the seashore, and } \\
\text { shall spread to the south, and to the north, and to the east; and all } \\
\text { the clans of the earth shall be multiplied in you and in your seed." }\end{array}$ \\
\hline
\end{tabular}

5 Metzger 1983:528.

6 Cf. Cf. Gen 21:2 in Profug 30; Gen 21:6 in Leg 2,21; 3,77; Det 33; Mut 24; Gen $21: 7$ in Migr 25; Gen 21:8 in Somn 2,10; Gen 21:10 in Cher 3 - the same verse that is also quoted by Paul in Gal 4:30 - Gen 21:14-16 in Sobr 2; Gen 21:19 in Post 38; Gen 21:25,26 in Somn 1,14; and Gen 21:33 in Plant 18, 20; Mut 35. References from the Thesaurus Linguae Graecae and Ryle 1895. 
Also later, during the first to the second century C.E. in the Testament of Abraham (8.4b-7), for instance, such allusions continued to occur (Sanders 1983:871-902).

\begin{tabular}{|l|l|}
\hline Test. Abr. 8.4b-7 & $\begin{array}{l}\text { "Go to my friend Abraham one more time and say this to } \\
\text { him: 'Thus says the Lord your God, who led you into the } \\
\text { promised land, who blessed you more than the sand of the } \\
\text { sea and the stars of heaven, who opened the womb of the } \\
\text { barren Sarah and graciously granted to you Isaac, the fruit } \\
\text { of the womb in old age. Truly I say to you that blessing I } \\
\text { will bless you and multiplying I will multiply your seed, } \\
\text { and I will give you whatever you ask of me; for I am the } \\
\text { Lord your God and besides me there is no other.", }\end{array}$ \\
\hline
\end{tabular}

\section{The Aqedah and confirmation of the promise}

In Jewish exegetical traditions, the Aqedah is the narrative trajectory of Abraham's binding (' $\bar{a} q a d)$ of Isaac to be sacrificed on the instruction of God (Gen 22:9). ${ }^{8}$ It became a popular story due to its elements of Abraham's obedience to God's test, his willingness to sacrifice his only son, and particularly Isaac's submission to the will of his father - elements that made it a "classic example of the redemptive efficacy of martyrdom" (O’Brien 2010:422). By referring to 2 Macc 7:9-14; 28-29, Koester (2001:491) rightly concludes that "resurrection faith enabled people to endure the martyrdom of themselves and their children". By presenting Abraham as a prototype of faithful endurance (Heb 6:15), who received God's promises, and interpreting the event as if Abraham received his son back from death (Heb 11:17-19), the unknown author of Hebrews alludes to the Aqedah tradition (Steyn 2011:213-214). The Aqedaic event as such is referred to in 4 Maccabees (first century C.E.) 13:12 and 18:11 - with a close resemblance in interpretation particularly between 4 Macc 16:20, 25 and Heb $11: 17,19 .^{9}$

7 Sanders (1983:886).

8 Cf. the extensive study of Steins (1999) on the Aqedah.

9 It is furthermore striking that Abraham is described as $\pi \iota \sigma \tau$ ó $\zeta$ in both 1 Macc 2:52 and Heb 11:17, whereas the Genesis account stresses his fear of God and his obedience (Ellingworth 2000:599-600). 


\begin{tabular}{|c|c|c|}
\hline 4 Macc $13: 12$ & 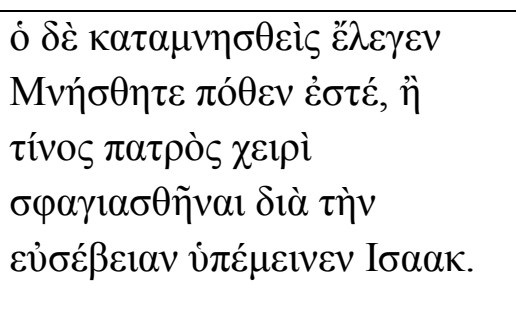 & $\begin{array}{l}\text { And another reminded them, } \\
\text { "Remember whence you come } \\
\text { and who the father was by whose } \\
\text { hand Isaak submitted to be } \\
\text { slaughtered for the sake of piety" } \\
\text { (NETS) }\end{array}$ \\
\hline $\begin{array}{l}4 \text { Macc 16:19- } \\
20\end{array}$ & 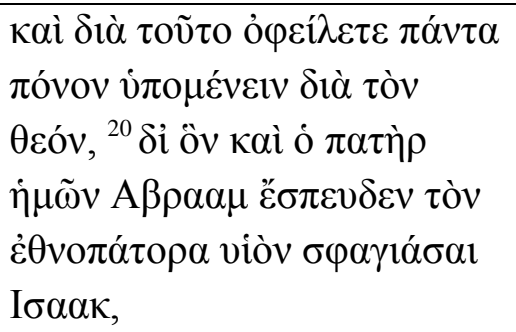 & $\begin{array}{l}\text { Therefore you ought to endure all } \\
\text { suffering for the sake of God, for } \\
\text { whose sake our father Abraham } \\
\text { made haste to sacrifice his son } \\
\text { Isaak, a father of our nation... } \\
\text { (NETS) }\end{array}$ \\
\hline Heb 11:17, 19 & 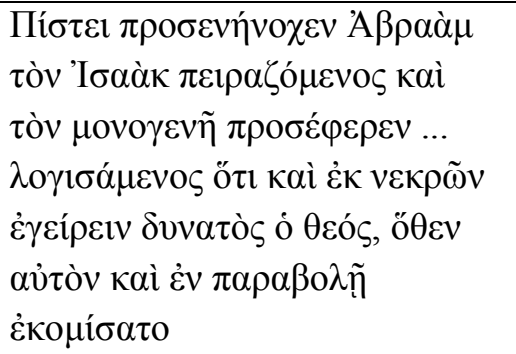 & $\begin{array}{l}\text { By faith Abraham, when God } \\
\text { tested him, offered Isaac, his one } \\
\text { and only son, as a sacrifice ... } \\
\text { Abraham reasoned that God could } \\
\text { raise the dead, and figuratively } \\
\text { speaking, he did receive Isaac } \\
\text { back from death (NIV). }\end{array}$ \\
\hline
\end{tabular}

Striking is Philo's wording that "Moses says that 'God tested Abraham..." (ó $\theta \varepsilon o ̀ s$

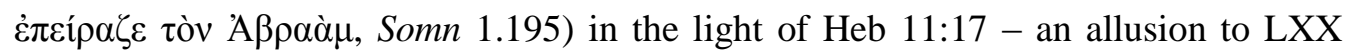

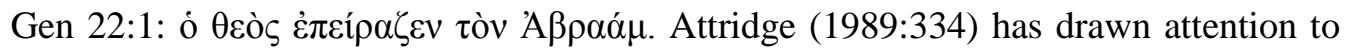
this aspect of the story that "played an important part in haggadaic traditions and it has special significance for Hebrews, whose addressees, like their High Priest, are being tested". A further allusion to the Aqedaic event also occurs in Philo's Leg 3.203 where he quotes Gen 22:16.

\begin{tabular}{|c|c|}
\hline \multirow[t]{2}{*}{$\begin{array}{l}\text { Philo, Leg } \\
3.203\end{array}$} & 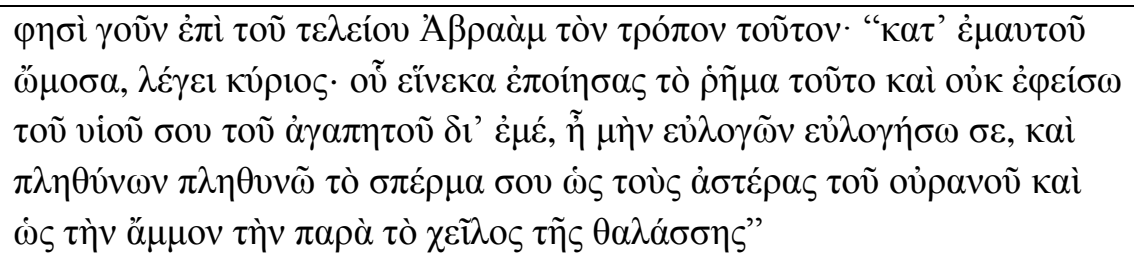 \\
\hline & $\begin{array}{l}\text { Accordingly he speaks with reference to the perfect man Abraham in the } \\
\text { following manner: "By myself have I sworn, said the Lord, that because }\end{array}$ \\
\hline
\end{tabular}


you had done this thing and had not withheld your son, your beloved son from me, that in blessing I will bless you, and in multiplying I will multiply your seed as the stars of heaven, and as the sand which is on the shore of the sea."10

\section{PRIESTS WITH ROYAL FUNCTIONS}

Plutarch (born 45 C.E.), the Greek biographer and philosopher, whilst writing on the ancient religion and philosophy of Egypt, referred to those at Heliopolis and to the fact that their kings were priests themselves. ${ }^{11}$ Kings were known to take on priestly functions as well. The opposite also happened, but was scarce. It was found particularly in the Maccabean period with Jonathan (1 Macc 10:20) and with Simon (1 Macc $14: 41,47 ; 15: 1-2){ }^{12}$

\section{Jonathan as ruler and high priest}

\begin{tabular}{|c|c|}
\hline \multirow[t]{2}{*}{1 Macc 9:30-31 } & 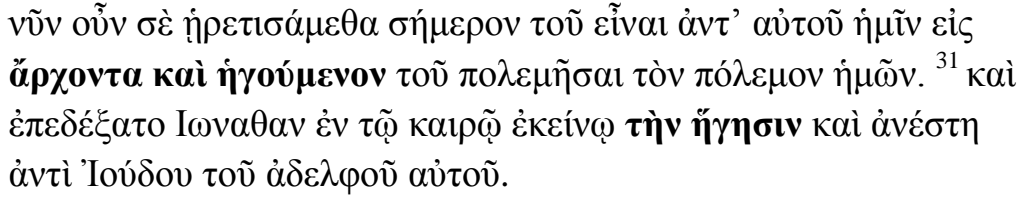 \\
\hline & $\begin{array}{l}\text { Now then we have chosen you today in his place to be for us a } \\
\text { ruler and a leader to fight our war. And Ionathan accepted the } \\
\text { leadership at that time and rose up in the place Ioudas his brother } \\
\text { (NETS). }\end{array}$ \\
\hline 1 Macc 10:20 & 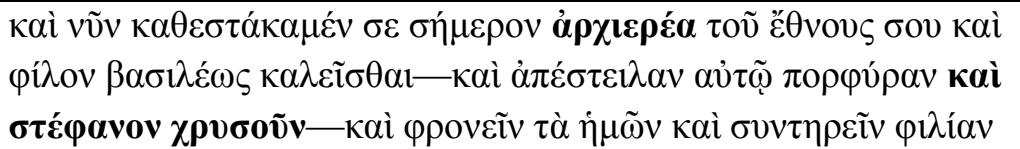 \\
\hline
\end{tabular}

10 Philo of Alexandria, and Yonge (1995:73).

11 Plutarch, De Iside et Osiride, Section 6 (Perseus Classics Collection), in Goodwin (1874:69).

12 Traces may also be found in T. 12Patr. (cf. T. Levi 5.1-7; 8.1-19; 17.1-11; 18.1-14; T. Jud. 24.1-6). Apocalyptic expected the renewal of the priesthood and a future priestly monarchy, the overcoming of sin and the opening of Paradise (Michel 1964:569). O'Brien (2010:193) has drawn attention to 1 Macc 7:5-9; 10:20; 11:27; 2 Macc 4:24, 29 and 14:3 in light of the Syrians who "violated the tradition by appointing high priests who lacked the appropriate qualifications, but who were thought to be "worthy of patronage or had outbid their competitors"”. 


\begin{tabular}{|l|l|}
\hline$\pi \rho o ̀ \varsigma ~ \eta \mu \tilde{\alpha} \varsigma$ \\
\cline { 2 - 2 } & $\begin{array}{l}\text { "And now we have appointed you today to be high priest of your } \\
\text { nation and to be called a Friend of the king" - and he sent him } \\
\text { purple vestments and a golden crown - "and to think about things } \\
\text { as we do and to keep friendship toward us" (NETS). }\end{array}$ \\
\hline
\end{tabular}

Apart from the combination between socio-political and religious leadership, it is also noteworthy to observe the resemblance in terminological preference for $\dot{\eta} \gamma o v$ $\mu \varepsilon v o v$ in 1 Maccabees and Hebrews. Especially interesting is the occurrence of this term in

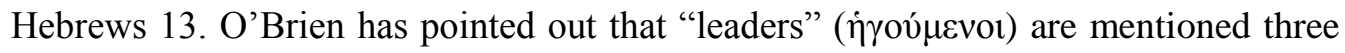
times here, namely in vv. 7, 17 and 24 (2010:515). Their role in the context of Heb

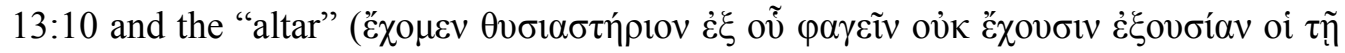
$\sigma \kappa \eta v \eta ̣ \tilde{~} \lambda \alpha \tau \rho \varepsilon v ́ o v \tau \varepsilon \varsigma)$ might point to similar connections between socio-political and religious leadership. ${ }^{13}$

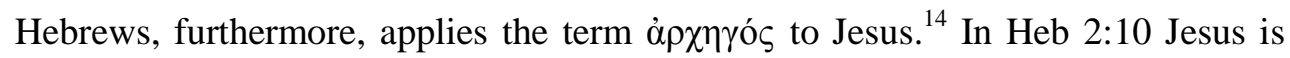

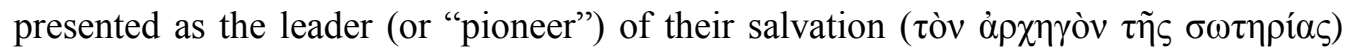
who was made perfect by God through suffering. In Heb 12:2 Jesus is again presented

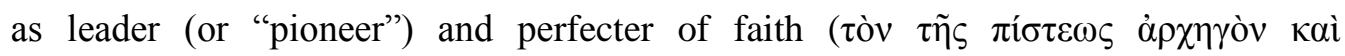

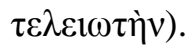

\section{Simon as governor and high priest}

\begin{tabular}{|c|c|}
\hline 1 Macc $14: 41$ & 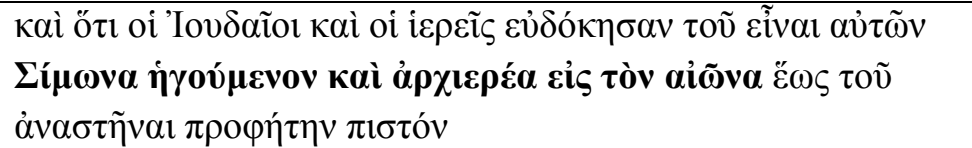 \\
\hline & $\begin{array}{l}\ldots \text { and that the Judeans and the priests were pleased that } \\
\text { Simon would be their leader and high priest forever, until a } \\
\text { faithful prophet would arise... }\end{array}$ \\
\hline 1 Macc 14:47 & 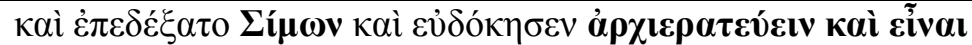 \\
\hline
\end{tabular}

13 For a list of interpretations of "the altar", see Koester (2001:568-569). Attridge (1989:396) has also drawn attention to the multiplicity of interpretations, "occasioned by the text's deliberate ambiguity" and sees it, quite rightly in my opinion, "as an introduction to the following verses".

14 Koester (2001:228-229) chose the translation "pioneer" as it "plays on both aspects of meaning", namely leader and founder. 


\begin{tabular}{|c|c|}
\hline & 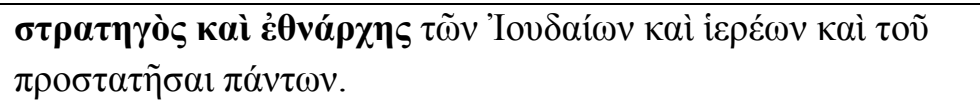 \\
\hline & $\begin{array}{l}\text { And Simon accepted and was pleased to be high priest and to } \\
\text { be commander and ethnarch of the Judeans and priests and } \\
\text { to protect all of them. }\end{array}$ \\
\hline 1 Macc $15: 1-2$ & 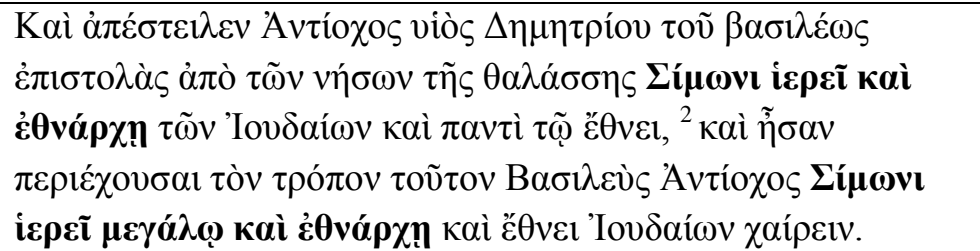 \\
\hline & $\begin{array}{l}\text { And Antiochus son of Demetrius the king sent letters from the } \\
\text { islands of the sea to Simon the priest and ethnarch of the } \\
\text { Judeans and to all the nation. And their contents were like this: } \\
\text { "King Antiochus to Simon the great priest and ethnarch and } \\
\text { the nation of the Judeans, greeting:" }\end{array}$ \\
\hline
\end{tabular}

Jonathan and Simon personify both rulership and priesthood - similar to Melchizedek as the ultimate example from the distant past. In this manner, the Maccabean history provides a convenient motif for the figure of Melchizedek as a comparative character for Christ by the author of Hebrews. Ellingworth (2000:521) has also drawn attention in Heb 10:2 to the "fusion (cf. 2:17) between the ideas of Christ as supreme ruler over (غ̇лí, 3:6) God's people and as high priest (similarly 1 Macc. 13:42, 'great high priest

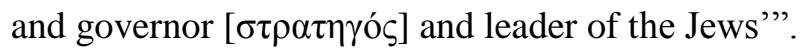

\section{Melchizedek as priest-king in Hebrews}

The unknown author of Hebrews refers to Melchizedek at a few places. The theme of Melchizedek is introduced in Heb 5:6 when he quotes Ps 110(109):4 - a verse that is quoted only by the author of Hebrews and by no other New Testament author. This quotation is repeated in Heb 7:17. ${ }^{15}$ In Heb 5:10 and 6:20 he puts the same quotation in his own words, where after he presents more information on "this Melchizedek" in

15 Lane (1998:184) points to an interesting resemblance between Heb 7:15-17 and 4 Macc

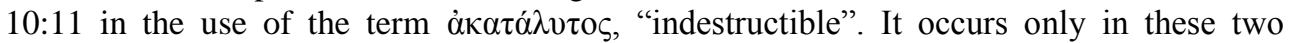
passages and "appears to have been carefully chosen". 
Heb 7:1-4. The author's exposition in Hebrews 7 on Melchizedek - which is in fact then an interpretation of Ps 110(109):4 - seems to follow the reading of Gen 14:17-20 when a number of phrases are quoted from that passage. The two most important elements for the argument about and interpretation regarding Melchizedek in Hebrews 7 are listed first: he is both king and priest. This combination of functions is important when linking Melchizedek to Jesus. Hebrews refers to Melchizedek as "king of Salem" and "priest of God the Most High". In the person of Melchizedek, the author conveniently finds the combination of a King-Priest ${ }^{16}$ - particularly based on the etymology of his name - one who is just and who fulfils the ritual requirements for the remission of sins.

\section{FAITH HEROES AND ENDURANCE}

The unknown author of Hebrews presents in Chapter 11 a list of examples from historical figures who should serve as role models of faith. They are the faith heroes who displayed endurance in their faith - irrespective of their circumstances. They were the ones who withstood the tests of their faith and who persevered in the challenges and suffering which they experienced. The list of Hebrews 11 is most likely the author's own selection of heroic figures and his own summative compilation of Jewish history. The narratives of many of these characters, such as Abraham, Moses, David, Daniel and others, surely would have been told by one generation to the next and their stories are to be found in a long lineage of Jewish literature. ${ }^{17}$ This includes, for instance, a similar list in 1 Macc 2:51-60 (the last words of Mattathias,

16 Koester (2001:346) quite rightly pointed out that "Israel's kings were commonly barred from priestly office even though they occasionally performed sacral functions. GrecoRoman kings commonly did serve as priests, and the emperor was widely acclaimed as 'high priest', yet the author of Hebrews does not appeal to a Greco-Roman precedent."

17 "As commentators point out, the genre of this catalogue of saints is quite in keeping with similar rehearsals of Israel's heroes found in contemporary Jewish writings" (Bockmuehl 2009:366). Alexander (2009:414) has drawn attention to the work of van Henten (2002) who highlighted three aspects of the martyrological discourse: "The Maccabean martyrologies evoke a list of biblical prototypes to encourage"; "the Maccabean stories draw on a typology of resistance"; and "the Maccabean martyrs collapse the distinction between active and passive resistance". 
father of Judas Maccabaeus and his brothers) - modelled on some quality worthy of emulation (O'Brien 2010:395). ${ }^{18}$ Mattathias mentions the pious achievements of

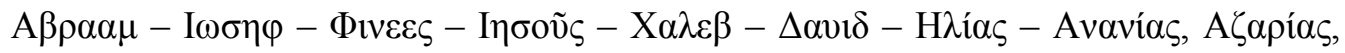

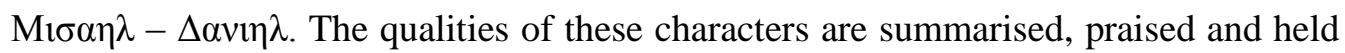
as examples:

${ }^{52}$ Was not Abraham found faithful in temptation, and it was imputed unto him for righteousness? ${ }^{53}$ Joseph in the time of his distress kept the commandment and was made lord of Egypt. ${ }^{54}$ Phinees our father in being zealous and fervent obtained the covenant of an everlasting priesthood. ${ }^{55}$ Jesus for fulfilling the word was made a judge in Israel. ${ }^{56} \mathrm{Caleb}$ for bearing witness before the congregation received the heritage of the land. ${ }^{57}$ David for being merciful possessed the throne of an everlasting kingdom. ${ }^{58}$ Elias for being zealous and fervent for the law was taken up into heaven. ${ }^{59}$ Ananias, Azarias, and Misael, by believing were saved out of the flame. ${ }^{60}$ Daniel for his innocency was delivered from the mouth of lions (1 Macc 2:52-60).

Another list can be found in 4 Macc $18: 11-13^{19}$ which praises the ancestors $A \beta \varepsilon \lambda-$

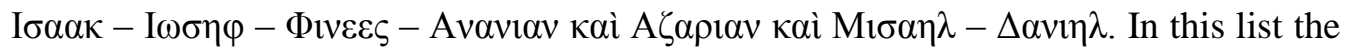
mother reminds her seven sons how their father transmitted the tradition of their forefathers to them:

He read to us of Abel who was slain by Cain, and of Isaac who was offered as a burnt-offering, and of Joseph in the prison. ${ }^{12}$ And he spake to us of Phineas, the zealous priest, and he taught you the song of Ananias, Azarias, and Mishael in the fire. ${ }^{13}$ And he glorified also Daniel

18 According to O'Brien (2010:395), Philo, in turn, presents "a collection of moral examples illustrated from the lives of Old Testament figures". Cf. Philo Virt. 198-255; Praem. 7-78; Leg. 2.53-59; 3.228.

19 "So in IV Macc 16:20ff., the mother of the seven martyr-brothers encourages her sons to faithful endurance by reminding them of Abraham, Daniel and the three Hebrews; in IV Macc 18:11 ff. She adds Abel, Isaac, Joseph and Phineas as examples for them to follow" (Bruce 1985:279). 
in the den of lions, and blessed him (4 Macc 18:11-13).

The references to the testing of Abraham, to Joseph, ${ }^{20}$ the spies (Joshua and Caleb), David, the prophets (Elijah), the three friends of Daniel (Ananias, Azarias, and Misael) and Daniel himself ${ }^{21}$ coincide in the lists of Hebrews 11 and 1 Maccabees 2. It is also interesting that the wording of Heb 11:17 closely resembles that of 1 Macc 2:52:

\begin{tabular}{|c|c|}
\hline 1 Macc 2:52 & 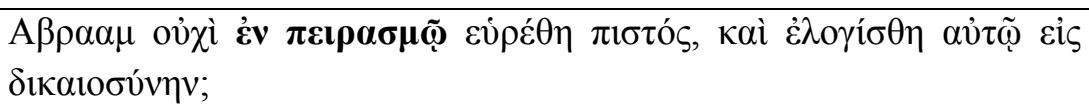 \\
\hline & $\begin{array}{l}\text { Was not Abraam found faithful in temptation, and it was accounted to } \\
\text { him for righteousness? (NETS) }\end{array}$ \\
\hline Heb 11:17 & 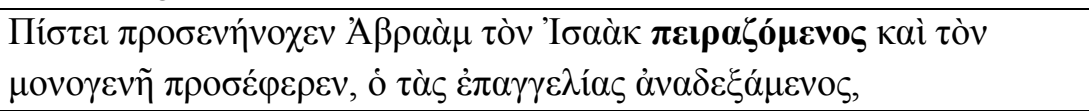 \\
\hline & $\begin{array}{l}\text { By faith Abraham, when God tested him, offered Isaac as a sacrifice. } \\
\text { He who had received the promises was about to sacrifice his one and } \\
\text { only son (NIV). }\end{array}$ \\
\hline
\end{tabular}

Furthermore, the wording of Heb 11:33-34 also closely resembles that of 1 Macc 2:59-60:

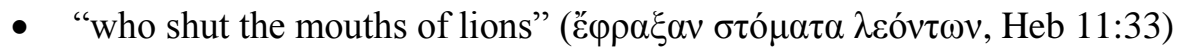

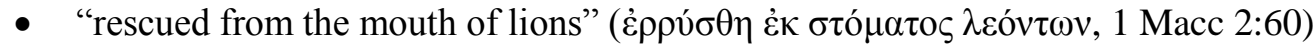

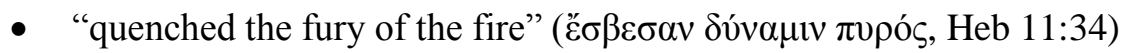

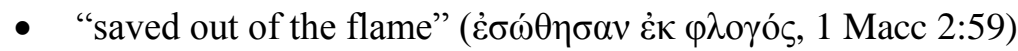

But the author of Hebrews included not only those well-known biblical characters such as Daniel and his three friends in his compilation. One also encounters references to - what seems to be - the Maccabean history itself. Hebrews 11:35a, for example, makes mention of women who "received back their dead, raised to life again" - which

20 F.F. Bruce refers to Ps 105:17-19; cf. Wisdom 10:13f.; I Macc 2:53; IV Macc 18:11. He states that "Joseph's career certainly presents instances of faith in abundance, such as his steadfastness under temptation and his patience under unjust treatment" (1985:314).

21 "Cf. the references to this incident in IV Macc 2:60 (where Mattathias on his deathbed reminds his sons how 'Daniel because of his innocence was delivered from the mouth of the lions'); IV Macc 16:3, 21; 18:13 (in the martyrology of the seven brothers and their mother)" (Bruce 1985:335). 
reminds of the torture and death of the seven sons and their mother as narrated in 2 Macc 7:1-42. Despite the fact that the king, after he tormented them with scourges and whips, pulled off the skin of their heads with the hair, made hot pans and caldrons, cut out the tongues and utmost parts of their bodies, and burnt them alive in the pan, they exhorted each other and found comfort in the Song of Moses. They were ready to die, rather than to transgress the laws of their fathers. The second son dies, saying that "the King of the universe will raise us up to an everlasting renewal of life, because we have died for his laws" (2 Macc 7:9) and the fourth son similarly states that "It is desirable that that those who die at the hands of human beings should cherish the hope God gives of being raised again by him" (2 Macc 7:14). The mother, who observed it all, had "hope in the Lord" and courageously remarked that the "Creator of the world" "will in his mercy give life and breath back to you again" (2 Macc 7:20, 23). She finally encourages her youngest son by saying, "Do not fear this hangman, but prove worthy of your brothers and accept death so that in his mercy I may get you back again along with your brothers" (2 Macc 7:29). Also 4 Maccabees reports about the mother who "showed her greater love for piety that, according to divine promise, preserves to everlasting life" (15:3) and who "because of the fear of God she despised the temporary deliverance of her children" (15:8).

The same applies to Heb 11:35b which refers to some who "were tortured but refused to be released, so that they might gain a better resurrection" 22 - which reminds of the Eleazar-narrative in 2 Macc 6:18-31, preceding and in close proximity with the previous narrative about the woman and her seven sons. ${ }^{23}$ Especially the references to $\tau u ́ \mu \pi \alpha v o v$ in 2 Macc 6:19 and 6:28 are striking. It is the only context in the LXX where the term is used in the sense of an instrument of torture, or the rack. The same is

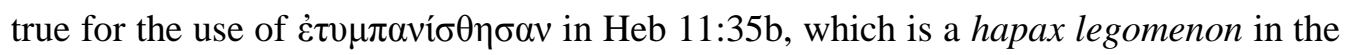
New Testament. Law (2013:66) observed that, "Beginning with the author of Hebrews, who apparently refers to the martyrs of 2 Maccabees in Hebrews 11:35-36,

22 For a discussion on resurrection in Hebrews, see Moffitt (2011). O'Brien (2010:443) pointed out that "Hebrews uses one of its characteristic words, 'better', to contrast it with the other resurrection mentioned in the verse" (i.e., Heb 11:35).

23 Ellingworth (2000:629) too is of the opinion that the author of Hebrews "has the Maccabees principally in mind" here. 
and going right through the last two millennia Christians have esteemed the Maccabean martyrs as forerunners of their own struggles."

Furthermore, it is especially Heb 11:37b-38 that reports of those who "wandered

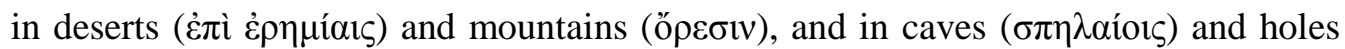
(ö $\pi \alpha \tilde{\zeta}$ ) in the ground". This is reminiscent of the report in 1 Macc 2:29-31, 36, where some Jews went to dwell in secret places in the wilderness ( the report in 2 Macc 5:27 which refers to Judas Maccabaeus who "kept himself and his

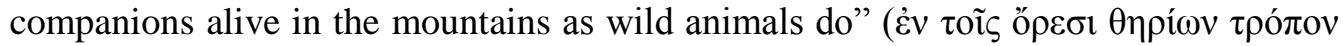

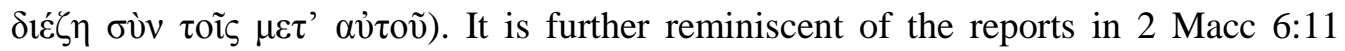
where others had run together into caves ( $\varepsilon \dot{i} \zeta \tau \grave{\alpha} \sigma \pi \hat{\eta} \lambda \alpha 1 \alpha$ ) nearby and were all burnt together, and to 2 Macc 10:6 which mentions that "they had been inhabiting the

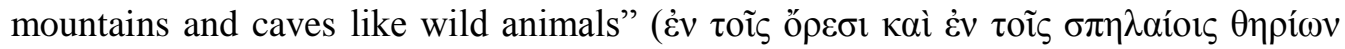

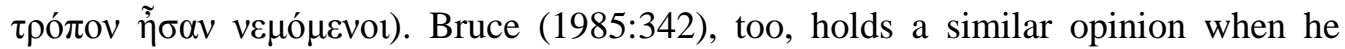
observes that

... the whole description of those who, roughly clad like this, endured restitution, affliction and ill-treatment as they wandered in desolate places and sought the shelter of caves, reminds us especially of those godly Jews who fled from the persecution under Antiochus Epiphanes - the 'wise among the people' who, in Daniel's vision, fell 'by the sword and by flame, by captivity and by spoil, many days' (Dan. 11:33). ${ }^{24}$ Such were the 'many who were seeking righteousness and justice' who, in the narrative of I Macc 2:29-38, 'went down to the wilderness to dwell there' with their families, 'because evil pressed heavily upon them'.

Ellingworth (2000:645) is also of the opinion that an allusion to 2 Macc 13:14 can be found in Heb 12:4. He qualifies: "The allusion to Judas Maccabaeus in 2 Macc. 13:14

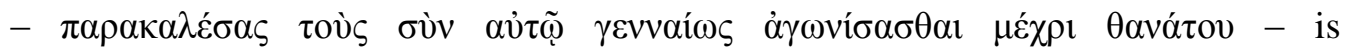
unmistakable, but the objects of their struggle ('the laws, the temple, the city ...') are different."

24 Cf. I Macc 2:28; II Macc 5:27; 6:11; 10:6 ("they had been wandering in the mountains and caves like wild animals"). 


\section{INSTRUCTION OF THE SCRIPTURES \\ Traces of the number ten for instruction in Philo}

Philo's use of $\pi \alpha 1 \delta \varepsilon i ́ \alpha$ in connection with education is interesting. In Sacr. 43, 63, and especially 122, he makes a link between Abraham and the number ten as the "number peculiar for instruction". Furthermore, we read that "Seth is the beginning of the just Noah; and his perfection $(\tau \varepsilon \lambda \varepsilon i \omega \sigma v)^{25}$ again is the beginning of the education

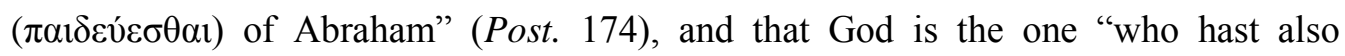

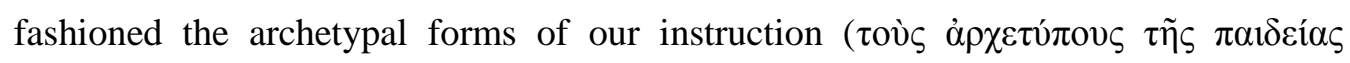
$\dot{\eta} \mu \tilde{\omega} v)$ while they were still indistinct, so as to make them visible, teaching Abraham wisdom (Somn. 1.173).

\section{Teaching the Law and the Prophets in 4 Macc 18:10-18: A comparison with Hebrews}

At the very end of 4 Maccabees, in 18:10-18f., one gets a glimpse of the "teaching of the Law and the Prophets" by the then already deceased father to his seven sons. An interesting list of ten teaching techniques that were utilised by their father is listed:

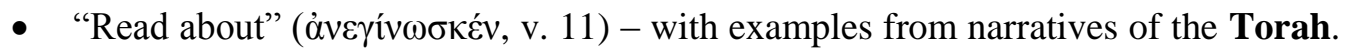

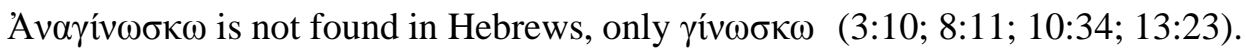

- "Told about" ( $\dot{\lambda} \varepsilon \gamma \varepsilon \varepsilon v$, v. 12) - example from the Torah. The verb $\lambda \dot{\varepsilon} \gamma \omega$ occurs frequently in Hebrews and is found 32 times.

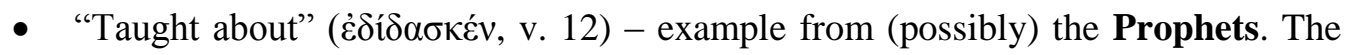
verb is only found in Heb 8:11.

- "Praised" ( $\dot{\varepsilon} \delta$ ó $\xi \alpha \zeta \varepsilon v, v .13$ ) - example from the Prophets. The verb occurs only in Heb 5:5, although the noun is found seven more times.

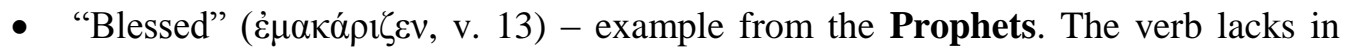
Hebrews, but the semantically related $\varepsilon \dot{\lambda} \lambda$ ó $\eta \sigma \varepsilon v$ is used (cf. 6:14; 7:1, 6, 7; 11:20, 21).

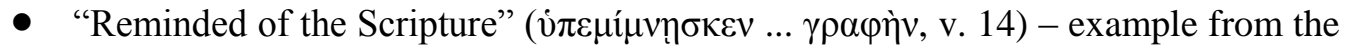

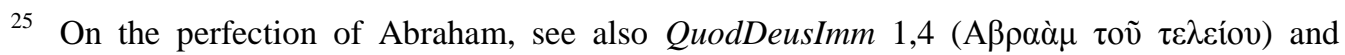

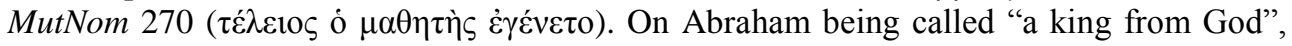
see Gen 23:6 and Philo MutNom 151-152; DeSomn 2,244. 


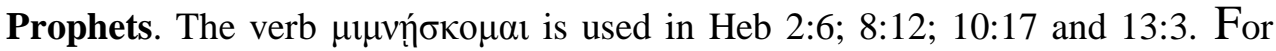
the only occurrence of $\gamma \rho \alpha \varphi \eta$, cf. Heb 10:7.

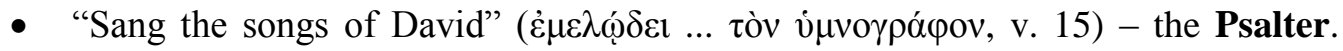
This particular verb does not occur in Hebrews, but the semantically related $\dot{v} \mu v \eta \dot{\sigma} \sigma \omega$ appears in the quotation from Ps 22(21) in Heb 2:12.

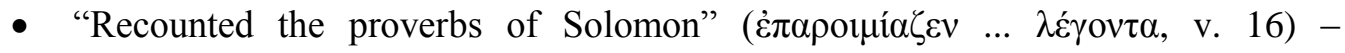
Proverbs. The verb $\pi \alpha \rho \circ \mu 1 \alpha \operatorname{\zeta } \omega$ is not found in Hebrews. In Heb 12:5 when the

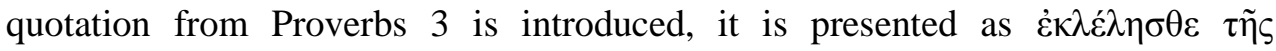

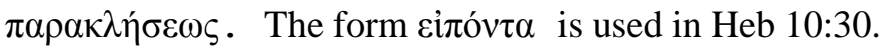

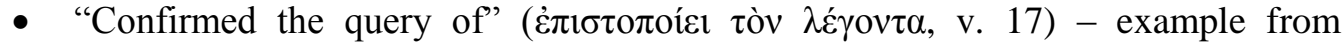
Prophets. The verb $\pi \imath \tau \tau$ Toté $\omega$ does not occur in Hebrews, but $\dot{\varepsilon} \beta \varepsilon \beta \alpha \iota \dot{\theta} \theta \eta$ is used in a similar context in Heb 2:3 about the fathers who confirmed what they have heard (cf. also Heb 6:16).

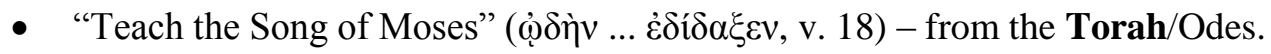
The list is structured in a kind of ring-compositional manner. The references from the Torah (two in the beginning and one at the end) form an inclusio, with those from the Prophets (five in total: first four, then one) ${ }^{26}$ inside this ring composition and the two poetic references in the centre. One can only speculate to what extent such a list might have been an established manner of teaching the Scriptures to children - especially in the light of Philo's reference to Abraham's choice of ten "as the number peculiar for instruction" (Sacr. 122). All the quoted texts in Hebrews display a similar pattern that alternates between a pair of quotations from the Torah and the Psalms with a pair from the Torah and the Prophets (cf. Steyn 2011:25-28).

\section{THE CANTICUM MOSIS}

Several pieces of literature testify to the importance of the Canticum Mosis for early

26 Gelardini (2011:127) has drawn attention to the research of Levine, who "localizes the introduction of the new readings during the Maccabean crisis, not evoked by Antiochus's decree but rather by a new esteem for prophetic literature in the context of politicalapocalyptic thinking." 
Judaism. Firstly, there are references to it that are found in Philo of Alexandria. ${ }^{27}$ Then there is, for instance, the Testament of Moses (alternatively known as the Apocalypse of Moses), which is "framed around the end of the book of Deuteronomy" 31-34 (Priest 1983:923) with evidence of an existing second century B.C.E. original (Kugel $\&$ Greer 1986:76). This in itself is an indication of the importance that this section in Deuteronomy had for early Judaism. But also the Maccabean literature holds the Song of Moses in high regard. There is a reference in 2 Macc 7:6 $6^{28}$ which quotes a line from Deut 32:36 (Fernández Marcos 2000:263), whilst another reference can be found in 4 Macc 18:18-19, which was probably written during the first century C.E. The mother of the seven sons also reminds them in this latter reference about the importance of the Song of Moses. This case had been used as evidence that the Canticum Mosis was sung during the Jewish Diaspora around the turn of the century (Schneider 1949:28$65)$.

Turning to Hebrews, the author quotes twice from the Song of Moses. ${ }^{29}$ In Heb 1:6 he quoted LXX Deut 32:43 (Ode 2:43). In Heb 10:30 he quotes again from Moses' song in Deuteronomy 32, but now from a few lines earlier, i.e., Deut 32:35, 36. The Canticum Mosis probably played a particular role during the cultic rituals and liturgical actions of some groups in early Judaism during the celebration of some festivals. At least two such festivals might have had connections with it. The first is the controversial festival of the renewal of the covenant. Those who accept its existence understand it as an annually repeated sacred act of the renewal of the covenant, attested in the Dead Sea Scrolls. ${ }^{30}$ If it is accepted, however, then the role that the Canticum Mosis played in it at Qumran during the liturgical function of this Song should certainly be taken into account when pondering its position in early Judaism and early Christianity. One can thus assume that in groups which saw themselves as "covenant communities" that this Canticum Mosis would have had an important liturgical role. But the Canticum Mosis was probably also used during the

27 See Philo Det. 114 (Deut 32:13); Leg. 3, 105 (Deut 32:34, 35); Plant. 59 (Deut 32:7-9).

28 NA28 lists the whole of 2 Macc 7:1-42 as background for the allusion in Heb 11:35.

29 I addressed this motif more extensively in two earlier contributions. See Steyn (2000:263272) and Steyn (2011:57-72; 300-310).

30 Cf. the Manual of Discipline 2:15. 
festival of the Day of Atonement, as testified in a Samaritan liturgical poem (Falk 1998:164). Hence, scholars assumed that the Song of Moses "furnished the early Christians with a remarkable number of testimonia" (Bruce 1985:262).

\section{CONCLUSION}

"Intertextuality understands that an author is a reader and reflector upon tradition" (Bredin 2003:20) who "transforms the meaning of an older text by the very fact of its reapplication and recontextualization in a new literary and historical context" (Stead 2012:362). The author of Hebrews reflects upon tradition, redactionally engages with it, and creates a new text which displays his reception history of the texts at his disposal - whether written or oral. This leaves us with two observations:

Observation \#1: Was the unknown author of Hebrews familiar with the books of the Maccabees?

Given the representative examples explored above, this would certainly be difficult to prove beyond doubt with regard to the Abrahamic Promise and the Aqedah, and also with regard to the Song of Moses. These motifs were widely known and inter-textual similarities are especially more common in 2 and 4 Maccabees. The motifs of priests who held kingly functions as well as faith heroes and their endurance display stronger connections with 1 Maccabees. If the author of Hebrews were familiar with the books of the Maccabees, then one might cautiously accept such familiarity with at least, either the book of 1 Maccabees, or with the common history and tradition of this book through oral history. We might find ourselves closer here to Roland Barthes' understanding of intertextuality, namely that an intertext refers to pieces of texts that were "anonymous, not possible to discover, but seem to have been read before" (van Luxemburg et al. 1983:78). It is certainly interesting to note that the author of Hebrews distinguishes himself from other New Testament authors who present a summary of Jewish history - such as Luke in Stephen's speech in Acts 7 - by including, what seems to be, events from the Maccabean history. In fact, scholars, 
such as Alexander (2009:413) ${ }^{31}$ and Ellingworth (2000:39) ${ }^{32}$ explicitly supported the assumption that the unknown author of Hebrews was indeed familiar with the Maccabean literature.

Observation \#2: Might some of these motifs and inter-textual similarities between common motifs in particularly 1 Maccabees, in Philo's works, and in Hebrews point to an Egyptian context?

This observation certainly requires further research. First Maccabees (which had a Hebrew original) and Second Maccabees (composed in Greek) originated probably between the end of the second century and the beginning of the first century B.C.E. against the backdrop of a Judean setting and under Seleucid rule. Third Maccabees, in turn, originated in Alexandria - also during the turn of the first century B.C.E. - but deals with Jewish life under Ptolemaic rule with pressures of Hellenization. Fourth Maccabees originated possibly during the first century C.E. in Antioch, Alexandria, or one of the Greek cities of Asia Minor and is written in the Greek philosophical diatribe style and is dependent on 2 Macc 6-7 (Law 2013:66-68). It is quite interesting that the complete collection of 1-4 Maccabees is only present in Codex Alexandrinus (fifth century C.E.), completely absent in Codex Vaticanus (fourth century C.E.), and only 1 and 4 Maccabees are present in Codex Sinaiticus (fifth century C.E.). A possible Alexandrian origin for Codex Alexandrinus is doubtful and debated so that no concrete connection between the Maccebean books and Hebrews could be made via Codex Alexandrinus per se. The Greek translation of the Hebrew original of 1 Maccabees was certainly known and used by Hellenistic Jews - certainly also in Alexandria. The same would apply to 2 Maccabees. Third Maccabees, in turn, probably originated anyway in an Alexandrian environment. Philo's connection with Alexandria is clear and Hebrews' connection with Alexandria is highly probable. Access to the Maccabean books in Alexandria, and even possible Alexandrian origins for 3 and 4 Maccabees, might be one explanation for the author of Hebrews'

31 Alexander (2009:413) writes: "The other key post-biblical tradition Hebrews is drawing on here is the tradition of the Maccabean martyrs, possibly 4 Macc ... later certainly 2 Macc 6-7."

32 Ellingworth (2000:39) wrote: "He seems, however, to have known, and used in other ways, many of the deuterocanonical writings, especially Wisdom, Sirach, and 1-4 Maccabees." 
intertextual connections with shared motifs between Philo and the Maccabean literature.

However, familiarity and preferential use of the particular common motifs explored above, need to be investigated against the broader background of the Ancient Near East and alongside a broader corpus of Jewish literature before such claims could be responsibly proposed. For now, suffice it to say that the author of Hebrews considers the Maccabean history as an integral part of the Jewish history in his summarized account of faith heroes who persevered and displayed a spirit of endurance.

\section{BIBLIOGRAPHY}

Alexander, L 2009. Prophets and martyrs as exemplars of faith, in Bauckham et al. 2009:405421.

Attridge, H W 1989. The epistle to the Hebrews. Hermeneia. Philadelphia: Fortress Press.

Barry, J D, Wentz, L, Mangum, D, et al. (eds) 2012-2014. The Lexham Bible dictionary. Bellingham, WA: Lexham Press.

Bauckham, R, Driver, D R, Hart, T A \& MacDonald, N (eds.) 2009. The epistle to the Hebrews and Christian theology. Grand Rapids: Eerdmans.

Bockmuehl, M 2009. Abraham's faith in Hebrews 11, in Bauckham et al. 2009:364-373.

Boda, M J \& McConville, G J (eds.) 2012. Dictionary of the Old Testament: Prophets. Downers Grove, IL: Inter-Varsity Press.

Bredin, M 2003. Jesus, revolutionary of peace: A nonviolent Christology in the book of Revelation. Milton Keynes: Paternoster.

Bruce, F F 1985. The epistle to the Hebrews. NICNT. Grand Rapids: Eerdmans.

Charlesworth, J H (ed.) 1983. The Old Testament Pseudepigrapha. Vol. 1: Apocalyptic literature and testaments. New York: Doubleday.

Ellingworth, P 2000. The epistle to the Hebrews. NIGTC. Grand Rapids: Eerdmans.

Evans, C A \& Porter, S E (eds) 2000. Dictionary of New Testament background: a compendium of contemporary biblical scholarship. Downers Grove, IL: InterVarsity Press.

Falk, D K 1998. Daily, sabbath, and festival prayers in the Dead Sea Scrolls. Leiden: Brill.

Fernández Marcos, N 2000. The Septuagint in context. Introduction to the Greek versions of the Bible. Leiden: Brill.

Gelardini, G 2011. Hebrews, homiletics, and liturgical Scripture interpretation, in Mason \& McCruden 2011:121-144.

Goodwin, W W (ed.) 1874. Plutarch's morals, Vol. 4 (Plutarch, De Iside et Osiride, Section 6). Perseus Classics Collection. Medford: Little, Brown, and Company.

Grässer, E 1990. An die Hebräer. 1. Teilband. Hebr 1-6. EKK XVII/1. Zürich: Benziger Verlag. 
1993. An die Hebräer. 2. Teilband. Hebr 7,1-10,18. EKK XVII/2. Zürich: Benziger

Verlag.

1997. An die Hebräer. 3. Teilband. Hebr 10,19-13,25. EKK XVII/3. Zürich: Benziger

Verlag.

Hauser, A J 2014. Biblical interpretation, a brief history of, in Barry et al. 2012-2014.

Karrer, M 2002. Der Brief an die Hebräer. Kapitel 1,1-5,10. ÖTKzNT 20/1. Gütersloh:

Gütersloher Verlagshaus.

2008. Der Brief an die Hebräer. Kapitel 5,11-13,25. ÖTKzNT 20/2. Gütersloh:

Gütersloher Verlagshaus.

Kistemaker, S 1961. The Psalm citations in the epistle to the Hebrews. Amsterdam: Van Soest.

Kittel, G (ed.) 1964. Theological dictionary of the New Testament. Vol. IV. Grand Rapids:

Eerdmans.

Klauck, H-J, et al. (eds) 2009. Encyclopedia of the Bible and its reception (EBR). Vol. I.

Berlin: Walter de Gruyter.

Koester, C 2001. Hebrews. AB 36. New York: Doubleday.

Kugel, J L \& Greer, R A 1986. Early biblical interpretation. Philadelphia: Westminster Press.

Law, T M 2013. When God spoke Greek: The Septuagint and the making of the Christian

Bible. New York: Oxford University Press.

Mason, E F \& McCruden, K B (eds) 2011. Reading the epistle to the Hebrews. A resource for students. Atlanta: SBL.

Metzger, B M 1983. The Fourth Book of Ezra, in Charlesworth 1983:517-560.

Moffitt, D M 2011. Atonement and the logic of resurrection in the epistle to the Hebrews.

Leiden: Brill.

Lane, W L 1998. Hebrews 1-8. WBC 47A. Dallas: Word Books. 1991. Hebrews 9-13. WBC 47B. Dallas: Word Books.

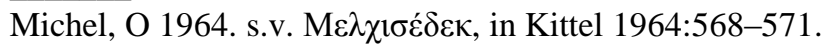

O'Brien, P T 2010. The letter to the Hebrews. Grand Rapids: Eerdmans.

Pietersma, A \& Wright, B G (eds) 2007. A new English translation of the Septuagint (NETS).

New York: Oxford University Press.

Priest, J 1983. Testament of Moses, in Charlesworth 1983:919-934.

Ryle, H E 1909. The canon of the Old Testament. London: Macmillan

Sanders, E P 1983. Testament of Abraham, in Charlesworth 1983:871-902.

Schneider, H 1949. Die biblischen Oden im christlichen Altertum, Bib 30:28-65.

Stead, M R 2012. Intertextuality and innerbiblical interpretation, in Boda and McConville 2012:355.

Steins, G 1999. Die 'Bindung Isaaks' im Kanon Gen 22. HBS 20. Freiburg: Herder.

Steyn, G J 2000. A quest for the Vorlage of the Song of Moses (Dt 32) quotations in Hebrews, Neot 34/2:263-272.

2011. A quest for the assumed LXX Vorlage of the explicit quotations in Hebrews.

FRLANT 235. Göttingen: Vandenhoeck \& Ruprecht.

Sutherland, D 1983. The organization of the Abraham promise narratives, ZAW 95:337-343.

Van Henten, J W \& Avemarie, F (eds) 2002. Martyrdom and noble death: selected texts from Graeco-Roman, Jewish and Christian antiquity. London: Routledge.

Van Luxemburg, J, Bal, M, Weststeijn, W G 1983. Inleiding in de literatuurwetenschap.

Muiderberg: Dick Coutinho.

Wall, R W 2000. Intertextuality, biblical, in Evans and Porter 2000:541-542.

Weiss, H-F 1991. Der Brief an die Hebräer. KEK 13. Göttingen: Vandenhoeck \& Ruprecht.

Yonge, C D 1995. The works of Philo: complete and unabridged. Peabody, MA: Hendrickson. 